\title{
Correction to: Construction and a preliminary study of paracrine effect of bone marrow-derived endothelial progenitor cell sheet
}

\author{
Fenlong Xue $\cdot$ Yunpeng Bai $\cdot$ Yiyao Jiang $\cdot$ Jianshi Liu $\cdot$ Kaitao Jian
}

Published online: 6 December 2021

(C) The Author(s) 2021

Correction to: Cell Tissue Bank

https://doi.org/10.1007/s10561-021-09932-w

In the original publication of the article, the author's name "Yuanfeng Xin (YX)" was incorrectly included in the Author Contribution statement.

Thus, the statement "FX and YX contributed equally to this work" is removed from the Author Contribution statement.

The original article has been corrected.

Open Access This article is licensed under a Creative Commons Attribution 4.0 International License, which

The original article can be found online at https:// doi.org/10.1007/s10561-021-09932-w.

F. Xue - Y. Jiang

Department of Cardiovascular Surgery, Tianjin First

Central Hospital, Tianjin 300192, China

Y. Bai · K. Jian $(\bowtie)$

Department of Cardiovascular Surgery, Tianjin Chest

Hospital, Tianjin 300051, China

e-mail: kaitao.jian@outlook.com

Y. Jiang

Department of Cardiovascular Surgery, The First

Affiliated Hospital of Bengbu Medical College,

Anhui 233004, China

J. Liu · K. Jian

Department of Cardiovascular Surgery, DeltaHealth

Hospital Shanghai, Shanghai 200336, China permits use, sharing, adaptation, distribution and reproduction in any medium or format, as long as you give appropriate credit to the original author(s) and the source, provide a link to the Creative Commons licence, and indicate if changes were made. The images or other third party material in this article are included in the article's Creative Commons licence, unless indicated otherwise in a credit line to the material. If material is not included in the article's Creative Commons licence and your intended use is not permitted by statutory regulation or exceeds the permitted use, you will need to obtain permission directly from the copyright holder. To view a copy of this licence, visit http://creativecommons.org/licenses/by/4.0/.

Publisher's Note Springer Nature remains neutral with regard to jurisdictional claims in published maps and institutional affiliations. 